\title{
Effects of Nd:YAG laser irradiation on the growth of Candida albicans and Streptococcus mutans: in vitro study
}

\author{
Kinga Grzech-Leśniak ${ }^{1}$ - Joanna Nowicka ${ }^{2}$ Magdalena Pajączkowska ${ }^{2}$. Jacek Matys ${ }^{3,4}$ (D) $\cdot$ Maria Szymonowicz $^{5}$. \\ Piotr Kuropka ${ }^{6}$ - Zbigniew Rybak $^{5}$ - Maciej Dobrzyński ${ }^{7}$ - Marzena Dominiak ${ }^{1}$
}

Received: 22 February 2018 / Accepted: 15 August 2018 / Published online: 25 August 2018

(C) The Author(s) 2018

\begin{abstract}
The purpose of this study was to evaluate the effects of Nd:YAG laser with flat-top handpiece on the in vitro growth of Candida albicans and Streptococcus mutans. The incidence of C. albicans (opportunistic commensal) and S. mutans (facultatively anaerobic) infections is increasing, despite available treatments. Cultures of Streptococcus mutans and Candida albicans were irradiated using Nd:YAG laser (LightWalker, Fotona) with flat-top handpiece (Genova, LightWalker, Fotona) at the following parameters: group G1: $0.25 \mathrm{~W}, 10 \mathrm{~Hz}, 15 \mathrm{~s}, 3 \mathrm{~J}$ and group G2: $1 \mathrm{~W}, 10 \mathrm{~Hz}$, $60 \mathrm{~s}, 59 \mathrm{~J}$. The results were evaluated directly and $24 \mathrm{~h}$ after irradiation using a quantitative culture method (estimation of colony-forming units in $1 \mathrm{ml}$ of suspension, $\mathrm{cfu} / \mathrm{ml}$ ), and microscopic analysis with Janus green stain and compared with control group in which laser was not applied. C. albicans was reduced by 20 up to $54 \%$ for G1, and for G2 by 10 up to $60 \%$ directly after the application. The cfu/ml values for $S$. mutans decreased by $13 \%(p=0.1771)$ for G1 and $89 \%(p<$ 0.0001 ) for G2. In both test groups $24 \mathrm{~h}$ after the application, the number of colony-forming units decreased by $15-46 \%$ for G1 and by $15-64 \%$ for G2. The arrested cell division, increasing the surface area and increasing the number of metabolically inactive cells, were observed in morphometric analysis. Macroscopic and microscopic analyses revealed a reduction in cell number and a significant decrease of cell metabolism after laser application for both $C$. albicans and $S$. mutans.
\end{abstract}

Keywords Biofilm $\cdot$ Cell metabolism $\cdot$ Flat-top handpiece $\cdot$ LLLT $\cdot$ Neodymium laser

Jacek Matys

jacek.matys@wp.pl

1 Department Oral Surgery, Wroclaw Medical University, Krakowska 26, 50-425 Wrocław, Poland

2 Department of Microbiology, Faculty of Medicine, Wroclaw Medical University, Chałubińskiego 4, 50-368 Wrocław, Poland

3 Private Dental Practice, Lipowa 18, 67-400 Wschowa, Poland

4 "Sapienza" University of Rome, Rome, Italy

5 Department of Experimental Surgery and Biomaterials Research, Wroclaw Medical University, Bujwida 44, 50-345 Wrocław, Poland

6 Department of Histology and Embriology, Wroclaw University of Environmental and Life Sciences, Norwida 31, 50-375 Wrocław, Poland

7 Department of Conservative Dentistry and Pedodontics, Wroclaw Medical University, Krakowska 26, 50-425 Wrocław, Poland

\section{Introduction}

The human oral cavity is a conducive environment to unrestricted formation of natural microbial biofilm. However, in a distorted equilibrium balance of the oral health, infectious pathogens may gain access into the dental tissues and gingival area. Infectious pathogens from the oral cavity cause oral diseases such as caries, gingivitis, periodontitis, endodontic infections, and alveolar osteitis, and sometimes are concomitant to systemic diseases, including cardiovascular disorders, stroke, preterm birth, diabetes, and pneumonia, among others $[1,2]$. Streptococcus mutans is one of the main bacterial strains colonizing the oral cavity and a major contributor of tooth decay, which in turn may affect the overall health of the host [3]. The fungal species of Candida albicans is by far the most commonly detected fungal organism in humans, part of the healthy human microbiota, but in immunocompromised hosts, it may cause a number of infections, ranging from superficial infections of the mucosa and skin to life-threatening 
systemic infections. C. albicans cells are frequently found along with $S$. mutans-derived plaque biofilms. Recent studies indicate high prevalence of $S$. mutans in dental biofilm where the fungal pathogen $C$. albicans resides, suggesting that this association is involved in the enhancement of biofilm virulence $[4,5]$. C. albicans coadheres with $S$. mutans in the presence of sucrose [5-7]. Such bacterium-fungus association may enhance $S$. mutans infection [8] and augment fungal carriage and infectivity of mucosal disease [9].

Management of infections caused by bacteria and fungi is a viable challenge in various medical fields, including dentistry. It cannot be emphasized enough that we need to focus on the search for alternative methods to manage rapidly developing drug resistance and recurrent candidiasis [10]. The development of laser medicine has provided a number of new therapy modalities capable of damaging pathogenic organisms. Photoantimicrobial therapy is safe, effective, and easy to implement and its activity spectrum covers bacteria, fungi, viruses, and protozoa, which make it superior to conventional therapies [11]. There are studies reporting antimicrobial and bactericidal effects of laser application [10]. Among them, one promising treatment modality is low-level laser therapy (LLLT), in which non-thermal laser irradiation is applied to the target site. LLLT uses mainly semiconductor lasers at 685 and $830 \mathrm{~nm}$ wavelengths, which are considered safe and effective against biofilm-associated infections [10]. In this study, Nd:YAG laser at $1064 \mathrm{~nm}$ was used based on the assumption that its characteristic qualities, high scattering effect, and deep soft tissue penetration could be more effective in reduction of $C$. albicans and $S$. mutans.

Antibacterial effects of Nd:YAG laser in patients treated for oral diseases have been confirmed in previous research, where pulsed Nd:YAG laser was applied with power settings over $2 \mathrm{~W}$ to induce a photothermal effect [12-14]. The efficacy of laser irradiation has been demonstrated against Escherichia coli, Staphylococcus aureus, Actinomyces naeslundii, Pseudomonas aeruginosa, Enterococcus faecalis, and Streptococcus anginosus $[12,15,16]$.

The present study aimed at evaluating the effects of laser therapy on pathogenic organisms commonly inhabiting the oral cavity using Nd:YAG with a flat-top handpiece. Flat-top handpiece spreads the energy of the laser beam evenly over the treated area in a no contact mode. It can be used at a variable distance of up to $100 \mathrm{~cm}$ without modifying the irradiation energy over a $1-\mathrm{cm}$ spot diameter. The handpiece is most commonly used for biostimulation and anti-inflammatory treatment. The present study explored the potential of Nd:YAG laser with flat-top handpiece to affect the in vitro growth of $S$. mutans and C. albicans - the two oral microbials which may become pathogenic in the presence of predisposing factors, producing infections that range from local to systemic.

\section{Material and methods}

To evaluate the effect of laser on selected cultures, quantitative culture technique (indicating the number of colony-forming units $[\mathrm{cfu}] / \mathrm{ml}$ ) and microscopic analysis with Janus green stain were used. All tested and control samples were subjected to triplicate procedure.

\section{Samples preparation}

Reference cultures of $S$. mutans (ATCC 25175) and $C$. albicans (ATCC 90028) and 3 clinical cultures of C. albicans collected from throat swab were selected for analysis (ethical approval by Research Ethics Board no. KB 342/2018). S. mutans and C. albicans colonies were subcultured from vial stock and a suspension was prepared $(0.5 \mathrm{McF}$ arland standard). S. mutans samples were inoculated in Columbia Agar with $5 \%$ sheep blood and incubated for $48 \mathrm{~h}$ at $37^{\circ} \mathrm{C}$ and increased level of $\mathrm{CO} 2$. C. albicans samples were inoculated in Sabouraud's dextrose agar for $48 \mathrm{~h}$ at $37^{\circ} \mathrm{C}$. Preparation of control inocula of $S$. mutans and C. albicans, respectively, followed the same procedure.

\section{Laser application}

The present study used a near-infrared neodymium-doped yttrium aluminum garnet, Nd:YAG laser (LightWalker, Fotona, Slovenia) at $1064 \mathrm{~nm}$ wavelength with flat-top handpiece (Genova, LightWalker, Fotona, Slovenia). The handpiece produces a spot size with a homogeneous beam profile of $\mathrm{Nd}$ :YAG laser light.

Table 1 Nd:YAG laser parameters used in the study

\begin{tabular}{llllllllll}
\hline $\begin{array}{l}\text { Study } \\
\text { group }\end{array}$ & Handpiece & $\begin{array}{l}\text { Distance } \\
(\mathrm{mm})\end{array}$ & $\begin{array}{l}\text { Energy } \\
(\mathrm{mJ})\end{array}$ & $\begin{array}{l}\text { Power } \\
(\mathrm{W})\end{array}$ & $\begin{array}{l}\text { Frequency } \\
(\mathrm{Hz})\end{array}$ & $\begin{array}{l}\text { Spot } \\
(\mathrm{mm})\end{array}$ & $\begin{array}{l}\text { Fluence }(\mathrm{J} / \\
\left.\mathrm{cm}^{2}\right)\end{array}$ & $\begin{array}{l}\text { Power density }(\mathrm{W} / \\
\left.\mathrm{cm}^{2}\right)\end{array}$ & $\begin{array}{l}\text { Total dose } \\
(\mathrm{J})\end{array}$ \\
\hline $\mathrm{G} 1$ & Genova & 10 & 25 & 0.25 & 10 & 10 & 0.03 & 0.32 & 3 \\
$\mathrm{G} 2$ & Genova & 10 & 100 & 1 & 10 & 10 & 0.13 & 1.27 & 59 \\
\hline
\end{tabular}

$\mathrm{cm}^{2}$ square centimeter, $\mathrm{Hz}$ Hertz, $J$ Joule, $m J$ millijoule, $m m$ millimeter; $W$ watt 
Table 2 The effect of laser on $S$. mutans viability (reference culture)
Streptococcus mutans (ATCC 25175)

\begin{tabular}{llll}
\hline G1 $\left(0.25 \mathrm{~W}, 10 \mathrm{~Hz}, 15 \mathrm{~s}, 3 \mathrm{~J} / \mathrm{cm}^{2}\right)$ & G2 $\left(1 \mathrm{~W}, 10 \mathrm{~Hz}, \mathrm{~s}, 59 \mathrm{~J} / \mathrm{cm}^{2}\right)$ & \\
\hline Control & $4 \times 10^{8} \mathrm{cfu} / \mathrm{ml}$ & Control & $8.90 \times 10^{9} \mathrm{cfu} / \mathrm{ml}$ \\
Directly after irradiation & $3.5 \times 10^{8} \mathrm{cfu} / \mathrm{ml}$ & Directly after irradiation & $9.40 \times 10^{8} \mathrm{cfu} / \mathrm{ml}$ \\
Control after 24 h & $4.5 \times 10^{8} \mathrm{cfu} / \mathrm{ml}$ & Control after $24 \mathrm{~h}$ & $7.40 \times 10^{9} \mathrm{cfu} / \mathrm{ml}$ \\
At 24 h after irradiation & $2.6 \times 10^{8} \mathrm{cfu} / \mathrm{ml}$ & At 24 h after irradiation & $4.02 \times 10^{9} \mathrm{cfu} / \mathrm{ml}$ \\
\hline
\end{tabular}

The investigation included two sets of parameters, changing the power and duration of irradiation. The following parameters were applied in two experimental groups:

Group 1 (G1): Genova handpiece, operation mode: pulsed wave (PW), power $0.25 \mathrm{~W}$ in non-contact mode, frequency $10 \mathrm{~Hz}$, energy $25 \mathrm{~mJ}$, distance $10 \mathrm{~mm}$, fluence per pulse $0.03 \mathrm{~J} / \mathrm{cm}^{2}$, power density per second $0.32 \mathrm{~W} / \mathrm{cm}^{2}$, spot diameter $10 \mathrm{~mm}$, time $15 \mathrm{~s}$, total dose $3 \mathrm{~J}$ (measured by $\mathrm{Nd}$ :YAG laser software).

Group 2 (G2): Genova handpiece, operation mode: pulsed wave ( $\mathrm{PW}$, power $1 \mathrm{~W}$ in non-contact mode, frequency $10 \mathrm{~Hz}$, energy $100 \mathrm{~mJ}$, distance $10 \mathrm{~mm}$, fluence per pulse $0.13 \mathrm{~J} / \mathrm{cm}^{2}$, power density per second $1.27 \mathrm{~W} / \mathrm{cm}^{2}$, spot diameter $10 \mathrm{~mm}$, time $60 \mathrm{~s}$, total dose $59 \mathrm{~J}$ (measured by Nd:YAG laser software) (Table 1).

Control group: non-irradiated reference and clinical cultures of S.mutans and C.albicans.

\section{Microorganism quantification}

The effect of laser on microorganisms (their viability in particular) was evaluated directly after laser irradiation and at $24 \mathrm{~h}$ after the application. One milliliter of each inocula was exposed to laser light at the fixed work distance of $1 \mathrm{~cm}$ (distance from light source and cell line surface) and then samples of $100 \mu \mathrm{l}$ were extracted to be seeded, ranging from $10^{-1}$ to $10^{-8} \mathrm{cfu} / \mathrm{ml}$. After incubation time macroscopic evaluation of the samples was performed to determine the $\mathrm{cfu} / \mathrm{ml}$ value. Preparation of control inocula of $S$. mutans and C. albicans, respectively, followed the same procedure as described for experimental samples, but they were not irradiated.
To evaluate the effect of laser light on the number of cells the $\mathrm{cfu} / \mathrm{ml}$ value for control samples was assumed $100 \%$. The change of cell number was calculated on the basis of:

$Z \mathrm{cfu} \%=100 \%-\left(\frac{\mathrm{cfuL}}{\mathrm{cfuK}} * 100 \%\right)$

Zcfu\% \% change of microorganism cells number $(\mathrm{cfu} / \mathrm{ml})$ after laser application

cfuL Value of colony-forming units in test samples (G1, G2) after laser application

cfuK Value of colony-forming units in control group

\section{Microscopic analysis with Janus green stain}

To ensure unbiased results, the researcher responsible for microscopic analysis was not informed of the content of the samples (double-blind trial). From the fresh culture of the analyzed strains, microorganism suspension concentration at 0.5 in McFarland Standard was prepared. One milliliter of such suspension was treated with laser (G1 and G2), centrifuged, and the sediment was applied on microscopic slide. After incubation time of $5 \mathrm{~min}$ in $1 \%$ of Janus green, the material was washed under tap water and covered by glass. Then, material was analyzed under microscope (Eclipse 80i, Nikon Instruments Inc., USA) in normal and polarized light. Morphometric analysis was performed with the use of NisElements AR (Nikon Instruments Inc., USA) software.

The microscopic analysis of the laser impact on microorganisms was performed directly after laser irradiation and after $24 \mathrm{~h}$. The control group was a suspension of the
Table 3 The effect of laser on $C$. albicans viability (reference culture)
Candida albicans (ATCC 90028)

\begin{tabular}{llll}
\hline G1 $\left(0.25 \mathrm{~W}, 10 \mathrm{~Hz}, 15 \mathrm{~s}, 3 \mathrm{~J} / \mathrm{cm}^{2}\right)$ & G2 $\left(1 \mathrm{~W}, 10 \mathrm{~Hz}, 60 \mathrm{~s}, 59 \mathrm{~J} / \mathrm{cm}^{2}\right)$ \\
\hline Control & $3.84 \times 10^{6} \mathrm{cfu} / \mathrm{ml}$ & Control & $3.32 \times 10^{6} \mathrm{cfu} / \mathrm{ml}$ \\
Directly after irradiation & $3.04 \times 10^{6} \mathrm{cfu} / \mathrm{ml}$ & Directly after irradiation & $2.50 \times 10^{6} \mathrm{cfu} / \mathrm{ml}$ \\
Control after 24 h & $4 \times 10^{7} \mathrm{cfu} / \mathrm{ml}$ & Control after $24 \mathrm{~h}$ & $2.73 \times 10^{8} \mathrm{cfu} / \mathrm{ml}$ \\
At 24 h after irradiation & $3.42 \times 10^{7} \mathrm{cfu} / \mathrm{ml}$ & At $24 \mathrm{~h}$ after irradiation & $9.9 \times 10^{7} \mathrm{cfu} / \mathrm{ml}$ \\
\hline
\end{tabular}


Table 4 The effect of laser on $C$. albicans [1] viability (clinical culture)

\begin{tabular}{llll}
\multicolumn{2}{l}{ Candida albicans [1] } \\
\hline G1 $\left(0.25 \mathrm{~W}, 10 \mathrm{~Hz}, 15 \mathrm{~s}, 3 \mathrm{~J} / \mathrm{cm}^{2}\right)$ & G2 $\left(1 \mathrm{~W}, 10 \mathrm{~Hz}, 60 \mathrm{~s}, 59 \mathrm{~J} / \mathrm{cm}^{2}\right)$ \\
\hline Control & $1.01 \times 10^{7} \mathrm{cfu} / \mathrm{ml}$ & Control & $9.3 \times 10^{6} \mathrm{cfu} / \mathrm{ml}$ \\
Directly after irradiation & $4.6 \times 10^{6} \mathrm{cfu} / \mathrm{ml}$ & Directly after irradiation & $5.6 \times 10^{6} \mathrm{cfu} / \mathrm{ml}$ \\
Control after $24 \mathrm{~h}$ & $3.77 \times 10^{8} \mathrm{cfu} / \mathrm{ml}$ & Control after $24 \mathrm{~h}$ & $3.54 \times 10^{9} \mathrm{cfu} / \mathrm{ml}$ \\
At $24 \mathrm{~h}$ after irradiation & $7.95 \times 10^{8} \mathrm{cfu} / \mathrm{ml}$ & At $24 \mathrm{~h}$ after irradiation & $7.2 \times 10^{9} \mathrm{cfu} / \mathrm{ml}$ \\
\hline
\end{tabular}

analyzed microorganisms prepared as above but not irradiated with laser light.

\section{Statistical analysis}

Data were analyzed using Analysis Tool Pack for MS Excel (Microsoft Corporation, Redmond, Washington, United States) with $\alpha=0.05$. Mann-Whitney test was used to analyze differences between test and control groups, between test groups and between reference and clinical colonies directly after laser application and $24 \mathrm{~h}$ after. To evaluate the significance of change between the given time points, Wilcoxon test was used to compare paired data. To ensure unbiased results, the researcher responsible for statistical analysis was not informed which data derived from macroscopic analysis referred to test and control groups (double-blind trial).

\section{Results}

\section{Quantitative analysis of the effect of laser on tested samples}

Directly after laser application on reference culture of $S$. mutans, the recorded values of $\mathrm{cfu} / \mathrm{ml}$ were $3.5 \times 10^{8}$ and $9.40 \times 10^{8}$ for G1 and G2, respectively. Twenty-four hours after the application, the values were $2.6 \times 10^{8}(\mathrm{G} 1)$ and $4.02 \times 10^{8}(\mathrm{G} 2)$ (Table 2).

Directly after laser application on reference and clinical cultures of $C$. albicans, the recorded values of $\mathrm{cfu} / \mathrm{ml}$ were in the range of $8 \times 10^{5}-4.6 \times 10^{6}$ for G1 and $2 \times 10^{5}-5.6 \times$ $10^{6}$ for G2. Evaluating cell viability $24 \mathrm{~h}$ after the application, the following values were recorded: $1.44 \times 10^{8}-$
$7.95 \times 10^{8} \mathrm{cfu}$ and $7.4 \times 10^{7}-7.2 \times 10^{9}$ for G1 and G2, respectively (Tables 3, 4, 5, and 6).

Directly after the application, the $\mathrm{cfu} / \mathrm{ml}$ values for $S$. mutans decreased by $13 \%(p=0.1771)$ for $\mathrm{G} 1$ and $89 \%(p<0.0001)$ for $\mathrm{G} 2$. The viability of $S$. mutans after laser irradiation were reduced by $42 \%(p<0.0001)$ for $\mathrm{G} 1$ and $46 \%(p<0.0001)$ for $\mathrm{G} 2$.

C. albicans cfu $/ \mathrm{ml}$ values were reduced by 20 up to $54 \%$ for $\mathrm{G} 1$, and for $\mathrm{G} 2$ by 10 up to $60 \%$ directly after the application. In both test groups $24 \mathrm{~h}$ after the application, the number of colony-forming units decreased by $15-46 \%$ for $\mathrm{G} 1$ and by $15-64 \%$ for G2. Statistically significant reduction of cfu/ $\mathrm{ml}$ value $(p<0.0001)$ was found for the majority of analyzed C. albicans cultures in both test groups (Fig. 1).

\section{Microscopic analysis}

Microscopic analysis of $S$. mutans cultures revealed reduction of the cell number and significant reduction in cell activity after laser application for G1. Some of the cells remained intact, but their metabolic activity was lower when compared to control group (Fig. 2b). Similar results were observed after application of laser for $\mathrm{G} 2$, where numerous remnants of the death cells remained attached to the slide glass. The metabolic activity of the cells in this group was weaker than in G1 group or there were none (Fig. 2).

As in the case of $S$. mutans, G1 laser application on $C$. albicans strains resulted in the reduction of cells compared to the control. Remnants from dead cells were observed among alive cells. In some cells, the nucleus was clearly visible, in some, it was not. In group G2, the cells started to change shape and numerous elongated cells with centrally situated nucleus were visible. The cells showed a different degree of dye absorption and oxidation (Fig. 3).
Table 5 The effect of laser on $C$. albicans [2] viability (clinical culture)
Candida albicans [2]

\begin{tabular}{llll}
\hline G1 $\left(0.25 \mathrm{~W}, 10 \mathrm{~Hz}, 15 \mathrm{~s}, 3 \mathrm{~J} / \mathrm{cm}^{2}\right)$ & $\mathrm{G} 2\left(1 \mathrm{~W}, 10 \mathrm{~Hz}, 60 \mathrm{~s}, 59 \mathrm{~J} / \mathrm{cm}^{2}\right)$ & \\
\hline Control & $3.3 \times 10^{6} \mathrm{cfu} / \mathrm{ml}$ & Control & $2 \times 10^{6} \mathrm{cfu} / \mathrm{ml}$ \\
Directly after irradiation & $3.3 \times 10^{6} \mathrm{cfu} / \mathrm{ml}$ & Directly after irradiation & $1.8 \times 10^{6} \mathrm{cfu} / \mathrm{ml}$ \\
Control after $24 \mathrm{~h}$ & $4.14 \times 10^{8} \mathrm{cfu} / \mathrm{ml}$ & Control after $24 \mathrm{~h}$ & $3.93 \times 10^{8} \mathrm{cfu} / \mathrm{ml}$ \\
At $24 \mathrm{~h}$ after irradiation & $2.45 \times 10^{8} \mathrm{cfu} / \mathrm{ml}$ & At $24 \mathrm{~h}$ after irradiation & $3.36 \times 10^{8} \mathrm{cfu} / \mathrm{ml}$ \\
\hline
\end{tabular}


Table 6 The effect of laser on $C$. albicans [3] viability (clinical culture)

\begin{tabular}{llll} 
Candida albicans [3] & & \\
\hline G1 $\left(0.25 \mathrm{~W}, 10 \mathrm{~Hz}, 15 \mathrm{~s}, 3 \mathrm{~J} / \mathrm{cm}^{2}\right)$ & $\mathrm{G} 2\left(1 \mathrm{~W}, 10 \mathrm{~Hz}, 60 \mathrm{~s}, 59 \mathrm{~J} / \mathrm{cm}^{2}\right)$ & \\
\hline Control & $1 \times 10^{6} \mathrm{cfu} / \mathrm{ml}$ & Control & $5 \times 10^{5} \mathrm{cfu} / \mathrm{ml}$ \\
Directly after irradiation & $8 \times 10^{5} \mathrm{cfu} / \mathrm{ml}$ & Directly after irradiation & $2 \times 10^{5} \mathrm{cfu} / \mathrm{ml}$ \\
Control after $24 \mathrm{~h}$ & $2.67 \times 10^{8} \mathrm{cfu} / \mathrm{ml}$ & Control after $24 \mathrm{~h}$ & $1.35 \times 10^{8} \mathrm{cfu} / \mathrm{ml}$ \\
At $24 \mathrm{~h}$ after irradiation & $1.44 \times 10^{8} \mathrm{cfu} / \mathrm{ml}$ & At $24 \mathrm{~h}$ after irradiation & $7.4 \times 10^{7} \mathrm{cfu} / \mathrm{ml}$ \\
\hline
\end{tabular}

Morphometric studies of the cell surface and analysis of metabolically active and inactive cells indicate that the cells are destroyed by the laser light (especially directly after the application). After $24 \mathrm{~h}$, further effects of laser irradiation were observed such as arrested cell division, increasing the surface area and increasing the number of metabolically inactive cells. This is confirmed by morphological observations. The analysis of the effects of laser irradiation revealed a statistically significant reduction $(p$ $<0.0001$ ) of both $C$. albicans and $S$. mutans cultures for both sets of parameters of laser application. In both cases (lower power and shorter irradiation (G1) and higher power and longer irradiation (G2)), the number of pathogens was reduced (Figs. 4 and 5, Table 7).

Higher power and longer irradiation in G2 provided more reduction of cfu/ml values of 3 cultures of C. albicans $24 \mathrm{~h}$ after the application than directly after irradiation. The decrease was statistically significant $(p<0.05)$. Such observations were not made for $S$. mutans strains.

Microscopic analysis with Janus green stain revealed changes in the number of analyzed microorganisms and changes in both their metabolic activity and shape. Janus green changes color according to the amount of oxygen present. When oxygen is present, the indicator oxidizes to a blue color. Different levels of dye absorption were observed after the application of G1 and G2 lasers and limited oxidation, which prove reduced cell metabolic activity. This observation was most evident for Streptococcus strains, in which inhibited metabolic activity and the change of color to blue were observed. It was also observed that some cells stopped absorbing the dye (lack of color). In the case of fungi, the effect was more profound after the application of lower power and shorter irradiation time (G1). After the application of higher power and longer irradiation time (G2), more cell debris could be seen after their disintegration, which indicates that laser may be more effective for cell destruction rather than inhibition of their activity. It is worth noting that the cells which were still active after the application of laser G2 tend to change shapes, elongate, and prepare to assume different morphological structure.

Laser light affects cell integrity directly after the application and $24 \mathrm{~h}$ after further effects could be observed, including inhibited cell division and increased number of metabolically inactive cells. In group $\mathrm{G} 1$, reduction of $\mathrm{cfu} / \mathrm{ml}$ values was observed for all analyzed cultures of $S$. mutans and $C$. albicans directly after the application and $24 \mathrm{~h}$ after irradiation. Higher power and longer irradiation time of laser G2 resulted in more reduction of colony-forming units of $S$. mutans and C. albicans directly after the application. In group $\mathrm{G} 2$, more effective reduction of $C$. albicans strains was observed $24 \mathrm{~h}$ after laser irradiation.

\section{Discussion}

Numerous studies on low-level laser therapy in combination with infrared lasers over the last 20 years provided positive results and thus a basis for the introduction of this technology
Fig. 1 Percent reduction of $S$. mutans and C. albicans after the application of laser. G1" 0 " directly after application; G2"0" directly after application; G1 "24" $24 \mathrm{~h}$ after application; G2"24" $24 \mathrm{~h}$ after application

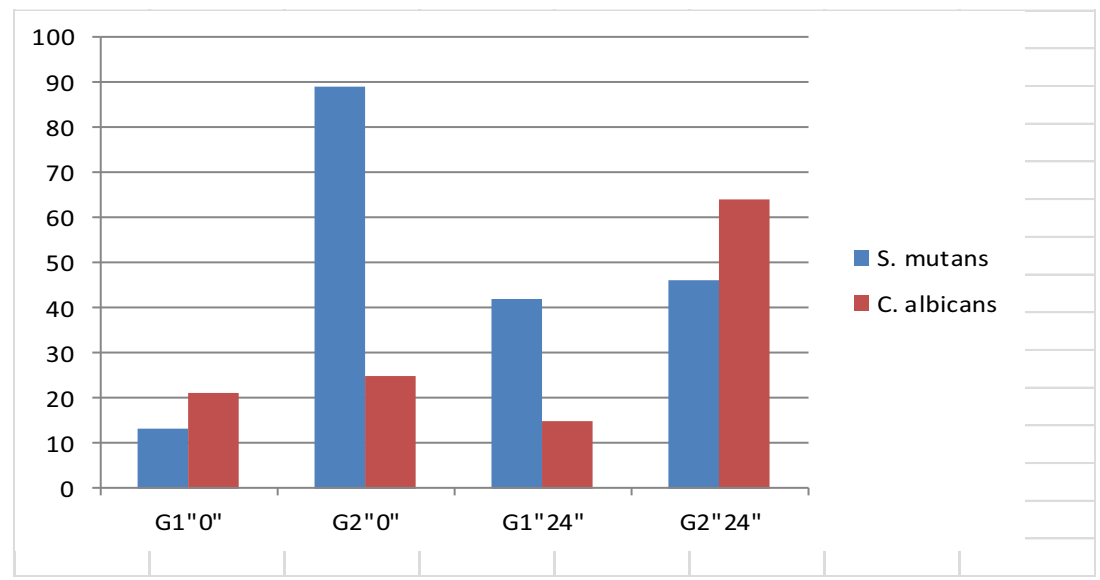



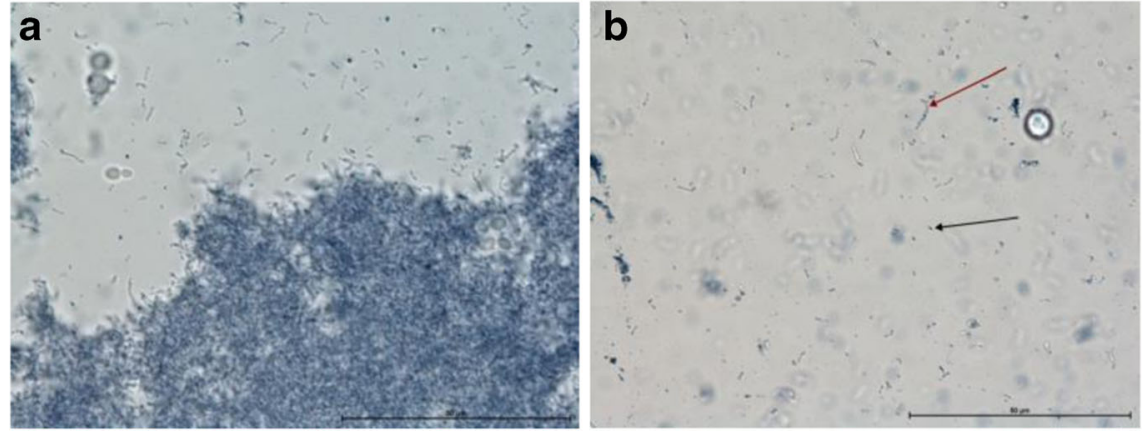

Fig. 2 Microscopic analysis of laser effect on reference cultures of $S$. mutans (ATCC 25175). a Control, aggregation of metabolically active bacteria; b G1, single bacteria (black arrow) and few colony-forming units (red arrow); c G2, numerous remnants of dead bacteria (black arrow). Streptococcus chains revealed different level of cell metabolism (red arrow); Janus green Mag. $\times 1000$ into clinical practice to stimulate wound healing, treat inflammation, and reduce pain [17-19]. However, development of new optical systems and handpieces to photons transport into a beam generated by Nd:YAG laser to the point of application demands verification of the knowledge of using LLLI on cells and tissues. Laser light has also been used in antimicrobial therapy. Studies indicate that laser application can effectively reduce or eliminate pathogenic organisms [20-23]. The study aimed at evaluating the effects of Nd:YAG irradiation on the in vitro growth of Candida albicans and Streptococcus mutans. The major finding of the study is that Nd:YAG laser with a flat-top handpiece resulted in the reduction of $C$. albicans and $S$. mutans at fluence below the soft tissue ablation threshold $\left(0.03\right.$ and $\left.0.13 \mathrm{~J} / \mathrm{cm}^{2}\right)$. Compared to the control group, irradiation using flat-top handpiece of Nd:YAG laser resulted in the decrease of the $\mathrm{cfu} / \mathrm{ml}$ value for both $C$. albicans and $S$. mutans. These findings indicate that $1064 \mathrm{~nm}$ infrared wavelength is efficient and safe in reduction of the total number of irradiated microorganisms.

Our review of the available literature provides no record of using Nd:YAG laser with the flat-top handpiece in both $C$. albicans and $S$. mutans irradiation. The analysis of the effects of laser irradiation revealed a statistically significant reduction of both $C$. albicans and S. mutans cultures for both sets of parameters of laser application. In both cases with a lower dose $(3 \mathrm{~J}$ at $0.25 \mathrm{~W}, 10 \mathrm{~Hz})$ or higher dose $(59 \mathrm{~J}$ at $1 \mathrm{~W}$, $10 \mathrm{~Hz}$ ), the number of pathogens was reduced.

A recent in vivo study by Piccolo et al. evaluated the effect of Nd:YAG irradiation to fight fungal overgrowth in the nail plate and indicated a great potential for safe and effective clinical application. The use of long-pulsed $1064 \mathrm{~nm}$ Nd:YAG laser (neodymium-doped yttrium aluminum garnet) for the treatment of Onychomycosis (caused by Candida species, among other pathogenic fungi) has demonstrated promising results [21]. However, the authors used the laser with $5 \mathrm{msec}$ pulse duration and $1 \mathrm{~Hz}$ repetition rate at the fluence of $30 \mathrm{~J} / \mathrm{cm}^{2}$, thus the fungal destruction was evoked strictly by photothermal effects what authors underline in the conclusion.

The use of LLLT with wavelength below $900 \mathrm{~nm}$ for $C$. albicans eradication was described in literature [20, 22-24]. Risovic et al. [20] observed the wavelength-dependent eradication efficiency of $C$. albicans, where most effective wavelength for elimination of $C$. albicans was UV-C $254 \mathrm{~nm}(\Delta=$ $6.1 \mathrm{~mJ} / \mathrm{cm}^{-2}$, ET99.99 $=56 \mathrm{~mJ} / \mathrm{cm}^{-2}$ ) and least efficient
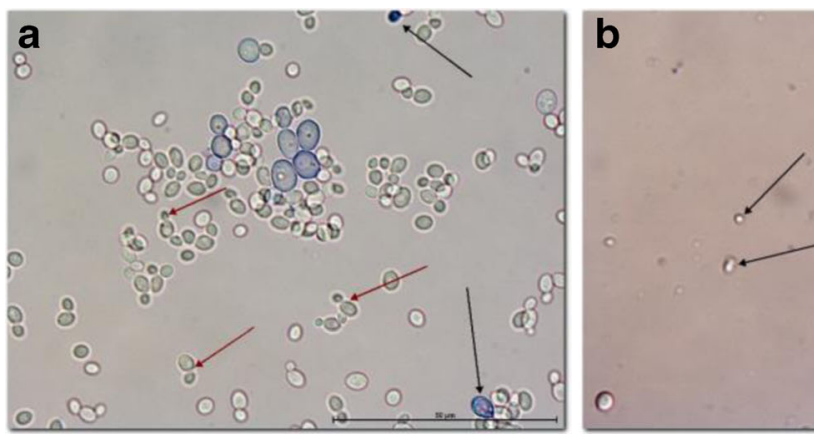

Fig. 3 Microscopic analysis of laser effect on clinical cultures of $C$. albicans 2 (sample photos). a Control, numerous cells of various sizes. Small cells have a green tinge, which is characteristic of metabolically active cells. They are often accompanied by smaller cells created as a result of budding (red arrow). Larger blue-colored cells (black arrow) display limited metabolic activity or are already inactive and signs of

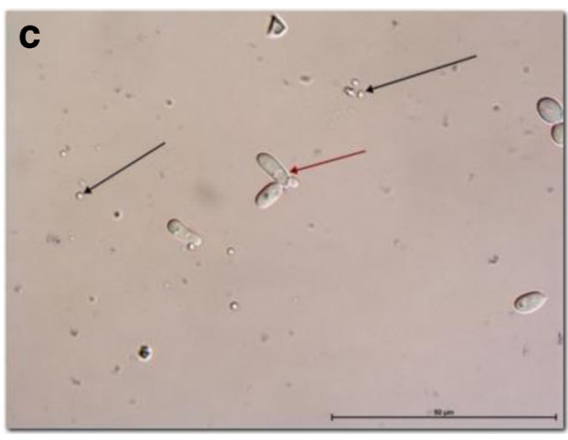

disintegration are visible. Degenerated cells appear in the smear as small, blue objects with unspecified morphology; b G1, visible remains of damaged cells (black arrow), single large cells grouped in 2 or 3 do not show the ability to absorb dye; c G2, debris from damaged cells. Some cells form clusters of 2-3 oval-shaped cells with separated nucleus (red arrow) and weak metabolic activity; Janus green; magnification of $\times 1000$ 
Fig. 4 Cell surface (in $\mu \mathrm{m}$ ) in the control and test (G1 and G2).

Statistical significance calculated for the confidence interval (95\%) alpha $=0.05$. Clinical strain $C$. albicans 1: C1 control; G1-1 after laser $\mathrm{G1}$; clinical strain $C$. albicans 2: C2 control: G1-2 after laser G1; G2-2 after the G2 laser

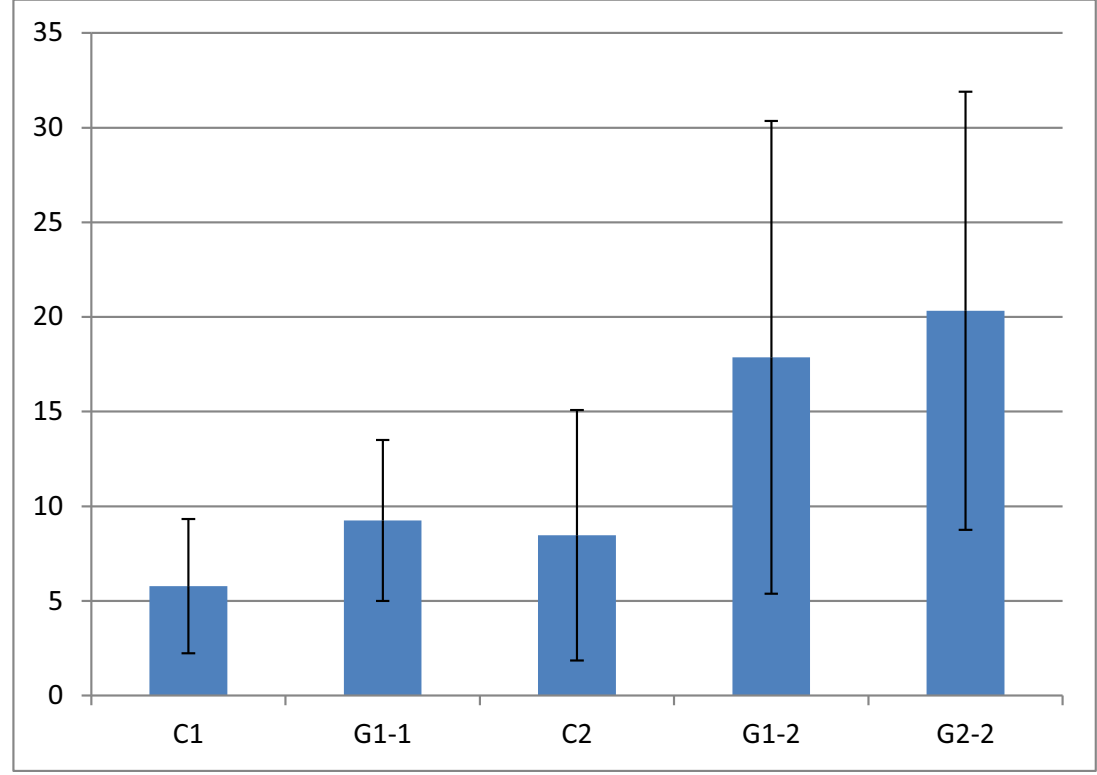

$406 \mathrm{~nm}\left(\Delta=11.4 \mathrm{~J} / \mathrm{cm}^{-2}\right.$, ET99.99=104 J/ $\left.\mathrm{cm}^{-2}\right)$. Gupta et al. [24] and Rosa et al. [22] confirmed that violet-blue visible light (400-490 nm) does not require the use of photosensitizer to kill $C$. albicans cells in biofilms. Other studies [10, 23] proved that laser light at $685 \mathrm{~nm}$ and $830 \mathrm{~nm}$ might be considered a promising treatment for C. albicans infections. Also, our present study showed the ability of 1064-nm Nd:YAG laser in eradication C.albicans at dose $3.0 \mathrm{~J} / \mathrm{cm}^{2}(0.25 \mathrm{~W})$ and $59 \mathrm{~J} / \mathrm{cm}^{2}(1 \mathrm{~W})$.

Seyedmousavi et al. [10] observed that LLLT with energies $>10 \mathrm{~J}$ at both 685 and $830 \mathrm{~nm}$ wavelengths produced statistically significant effects in vitro on the pathogenicity of $C$. albicans, and in vivo on the survival rate of mice ( $p$ value $\leq$ 0.05). In turn, Maver-Biscanin et al. [23] in their in vivo study reduction of $C$. albicans species in the treated areas were irradiated with different exposure times $-5 \mathrm{~min}(830 \mathrm{~nm}, 3.0 \mathrm{~J} /$ $\left.\mathrm{cm}^{2}, 60 \mathrm{~mW}\right)$ and $10 \mathrm{~min}\left(685 \mathrm{~nm}, 3.0 \mathrm{~J} / \mathrm{cm}^{2}, 30 \mathrm{~mW}\right)$. In contrast to above-mentioned studies [10, 23] efficient eradication of $C$. albicans and $S$. mutans was found with an exposure time $15 \mathrm{~s}\left(3.0 \mathrm{~J} / \mathrm{cm}^{2}, 250 \mathrm{~mW}\right)$ and $60 \mathrm{~s}\left(59 \mathrm{~J} / \mathrm{cm}^{2}\right.$, $1000 \mathrm{~mW}$ ).

In the literature was described very well that the laser light generated by the infrared lasers with wavelengths in the range of 600-1100 $\mathrm{nm}$ affects a wider cell-light response [25]. The dose-dependent effects of LLLT are described by the ArndtSchultz's curve $[25,26]$. It suggests that different types of stimuli evoke different reactions of cells, e.g., increased stimulus inhibits activity [26]. On the other hand, the bacterial eradication can be obtained in a different process by photodynamic therapy where the irradiated photosensitizer generates induction of reactive oxygen species (ROS) which have a high killing potential for bacteria, fungus, and viruses. Despite the above-mentioned photodynamic effects of LLLT, literature review provides numerous studies on the influence of light on stimulation and inhibition of bacterial growth in the dose range of $1-10 \mathrm{~J} / \mathrm{cm}^{2}$ without administration of
Fig. 5 Percentage of metabolically inactive cells in the control and test samples. Clinical strain C. albicans 1: C1 control; G1-1 after laser G1; clinical strain C. albicans 2: $\mathrm{C} 2$ control: G1-2 after laser G1; G2-2 after the G2 laser

\section{Percentage of metabolically inactive cells}

(\%)

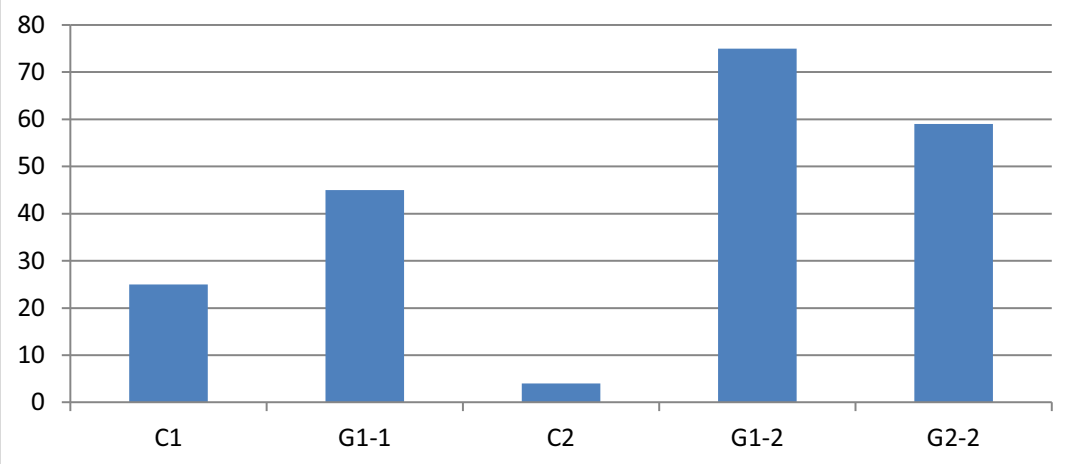


Table 7 Statistical significance calculated for the confidence interval (95\%) alpha $=0.05$

\begin{tabular}{llllll}
\hline $\begin{array}{l}\text { Group/ } \\
\text { sample }\end{array}$ & C1 & G1-1 & C-2 & G1-2 & G2-2 \\
\hline C1 & & + & - & + & + \\
G1-1 & + & & - & + & + \\
C2 & - & - & & + & + \\
G1-2 & + & + & + & & - \\
G2-2 & + & + & + & - & \\
\hline
\end{tabular}

Clinical strain C. albicans 1: C1 control; G1-1 after laser G1; Clinical strain C. albicans 2: C2 control: G1-2 after laser G1; G2-2 after the G2 laser

photosensitizers [10]. This effect was defined by the generation of ROS elicited by activation of endogenous chromophores in cells by the infrared laser light [10]. Thus, the results of our study where the irradiation with the two different doses $(3 \mathrm{~J}$ at $0.25 \mathrm{~W} / 10 \mathrm{~Hz}$ or $59 \mathrm{~J}$ at $1 \mathrm{~W} / 10 \mathrm{~Hz}$ ) resulted in a reduction in $\mathrm{S}$. mutans and $C$. albicans amount in the same session can be explained by this above-mentioned phenomenon. The effect of laser on bacterial/fungal destruction was also described by Sommer where the expansion and contraction of the intracellular water volume and fluidity generate bidirectional flow [27].

In our opinion, Nd:YAG laser light at $1064 \mathrm{~nm}$ which is closed to the third peak wavelength of $1000 \mathrm{~nm}$ causes photoexcitation of endogenous microbial porphyrin molecules contained in $S$. mutans and $C$. albicans evoking oxidative damage through reactive oxygen species (ROS).

Translating our data into the clinical setting, we suggest that laser-based antimicrobial treatment can significantly reduce the quantity of Streptococcus mutans and Candida albicans especially in the treatment of caries and candidiasis.

More clinical studies are needed to evaluate the efficacy of a direct laser-based approach in vivo. Further study of $\mathrm{Nd}$ :YAG application with the Genova handpiece to treat bacterial and fungal infection is still needed to assess the efficacy of Nd:YAG $1064 \mathrm{~nm}$ laser therapy as a valid treatment for this frequent pathology.

\section{Conclusions}

The present data suggest that laser light at specific wavelengths might have some positive effects on the reduction of S. mutans and C. albicans infections; however, the clinical studies should be performed. Laser irradiation merits further attention for the many advantages it offers: shorter treatment duration, lower cost of treatment, minimal or no side effects, and an alternative to the systemic administration of antibiotics. Both low- and high-intensity Nd:YAG laser can significantly reduce the quantity of Streptococcus mutans and Candida albicans, which can be obtained after further clinical studies.

Funding This study was self-funded.

\section{Compliance with ethical standards}

Conflict of interest The authors declare that they have no conflict of interest.

Ethical approval The use of the throat swabs was approved by Research Ethics Board (KB 342/2018).

Informed consent The informed consent was not required for this in vitro study.

Open Access This article is distributed under the terms of the Creative Commons Attribution 4.0 International License (http:// creativecommons.org/licenses/by/4.0/), which permits unrestricted use, distribution, and reproduction in any medium, provided you give appropriate credit to the original author(s) and the source, provide a link to the Creative Commons license, and indicate if changes were made.

\section{References}

1. Lucchese A (2017) Streptococcus mutans antigen I/II and autoimmunity in cardiovascular diseases. Autoimmun Rev 16(5):456-460

2. Grzech-Leśniak K (2017) Making use of lasers in periodontal treatment: a new gold standard? Photomed Laser Surg 35(10):513-514

3. Takahashi N, Nyvad B (2011) The role of bacteria in the caries process: ecological perspectives. J Dent Res 90(3):294-303

4. Falsetta ML, Klein MI, Colonne PM, Scott-Anne K, Gregoire S, Pai C-H et al (2014) Symbiotic relationship between Streptococcus mutans and Candida albicans synergizes virulence of plaque biofilms in vivo. Infect Immun 82(5):1968-1981

5. Metwalli KH, Khan SA, Krom BP, Jabra-Rizk MA (2013) Streptococcus mutans, Candida albicans, and the human mouth: a sticky situation. PLoS Pathog 9(10):e1003616

6. Bergendal T, Forsgren L, Kvint S, Löwstedt E (1989) The effect of an airbrasive instrument on soft and hard tissues around osseointegrated implants. A case report. Swed Dent J 14(5):219 223

7. Pereira DFA, Seneviratne CJ, Koga-Ito CY, Samaranayake LP (2018) Is the oral fungal pathogen Candida albicans a cariogen? Oral Dis 24(4):518-526

8. Shirtliff ME, Peters BM, Jabra-Rizk MA (2009) Cross-kingdom interactions: Candida albicans and bacteria. FEMS Microbiol Lett 299(1): $1-8$

9. Xu H, Sobue T, Thompson A, Xie Z, Poon K, Ricker A et al (2014) Streptococcal co-infection augments Candida pathogenicity by amplifying the mucosal inflammatory response. Cell Microbiol 16(2): 214-231

10. Seyedmousavi S, Hashemi SJ, Rezaie S, Fateh M, Djavid GE, Zibafar E et al (2014) Effects of low-level laser irradiation on the pathogenicity of Candida albicans: in vitro and in vivo study. Photomed Laser Surg 32(6):322-329

11. Wainwright M, Maisch T, Nonell S, Plaetzer K, Almeida A, Tegos GP et al (2017) Photoantimicrobials - are we afraid of the light? Lancet Infect Dis 17(2):e49-e55

12. Vescovi P, Conti S, Merigo E, Ciociola T, Polonelli L, Manfredi M et al (2013) In vitro bactericidal effect of Nd: YAG laser on Actinomyces israelii. Lasers Med Sci 28(4):1131-1135 
13. Gómez C, Domínguez A, García-Kass AI, García-Nuñez JA (2011) Adjunctive Nd: YAG laser application in chronic periodontitis: clinical, immunological, and microbiological aspects. Lasers Med Sci 26(4):453-463

14. Yasuda Y, Kawamorita T, Yamaguchi H, Saito T (2010) Bactericidal effect of Nd: YAG and Er: YAG lasers in experimentally infected curved root canals. Photomed Laser Surg 28(S2):S75-S-8

15. Bergmans L, Moisiadis P, Teughels W, Van Meerbeek B, Quirynen M, Lambrechts P (2006) Bactericidal effect of Nd: YAG laser irradiation on some endodontic pathogens ex vivo. Int Endod J 39(7): $547-557$

16. Franzen R, Gutknecht N, Falken S, Heussen N, Meister J (2011) Bactericidal effect of a Nd: YAG laser on Enterococcus faecalis at pulse durations of 15 and $25 \mathrm{~ms}$ in dentine depths of 500 and 1,000 $\mu \mathrm{m}$. Lasers Med Sci 26(1):95-101

17. de Paula Eduardo C, de Freitas PM, Esteves-Oliveira M, Aranha ACC, Ramalho KM, Simões A et al (2010) Laser phototherapy in the treatment of periodontal disease. A review. Lasers Med Sci 25(6):781-792

18. Ge M, He W, Chen J, Wen C, Yin X, Hu Z et al (2015) Efficacy of low-level laser therapy for accelerating tooth movement during orthodontic treatment: a systematic review and meta-analysis. Lasers Med Sci 30(5):1609-1618

19. Ren C, McGrath C, Yang Y (2015) The effectiveness of low-level diode laser therapy on orthodontic pain management: a systematic review and meta-analysis. Lasers Med Sci 30(7):1881-1893
20. Risović D, Maver-Bišćanin M, Mravak-Stipetić M, Bukovski S, Bišćanin A (2014) Quantitative investigation of efficiency of ultraviolet and visible light in eradication of Candida albicans in vitro. Photomed Laser Surg 32(4):232-239

21. Piccolo D, Kostaki D, Del Duca E, Cannarozzo G, Sannino M, Nisticò S (2017) Long-pulsed 1064-nm Nd: YAG laser for the treatment of onychomycosis. Photomed Laser Surg 35(4):213-216

22. Rosa LP, Da Silva FC, Viana MS, Meira GA (2016) In vitro effectiveness of 455-nm blue LED to reduce the load of Staphylococcus aureus and Candida albicans biofilms in compact bone tissue. Lasers Med Sci 31(1):27-32

23. Maver-Biscanin M, Mravak-Stipetic M, Jerolimov V (2005) Effect of low-level laser therapy on Candida albicans growth in patients with denture stomatitis. Photomed Laser Ther 23(3):328-332

24. Gupta S, MacLean M, Anderson J, MacGregor S, Meek R, Grant M (2015) Inactivation of micro-organisms isolated from infected lower limb arthroplasties using high-intensity narrow-spectrum (HINS) light. J Bone Joint Surg Br 97(2):283-288

25. Huang Y-Y, Sharma SK, Carroll J, Hamblin MR (2011) Biphasic dose response in low level light therapy-an update. Dose-Response 9(4):11-009 dose-response, Hamblin

26. Oron U, Yaakobi T, Oron A, Hayam G, Gepstein L, Rubin O et al (2001) Attenuation of infarct size in rats and dogs after myocardial infarction by low-energy laser irradiation. Lasers Surg Med 28(3): 204-211

27. Sommer AP (2007) Antiinfectives and low-level light: a new chapter in photomedicine. Photomed Laser Surg 25(3):150-158 